\title{
Baseline survey of Nigerian media coverage of youth sexual and reproductive health and HIV and AIDS related issues, January 1st-December 31st, 2012
}

Population Council

Follow this and additional works at: https://knowledgecommons.popcouncil.org/departments_sbsr-hiv

Part of the Demography, Population, and Ecology Commons, Family, Life Course, and Society Commons, International Public Health Commons, and the Journalism Studies Commons How does access to this work benefit you? Let us know!

\section{Recommended Citation}

Population Council. 2014. "Baseline survey of Nigerian media coverage of youth sexual and reproductive health and HIV and AIDS related issues, January 1st-December 31st, 2012." Abuja: Population Council. 


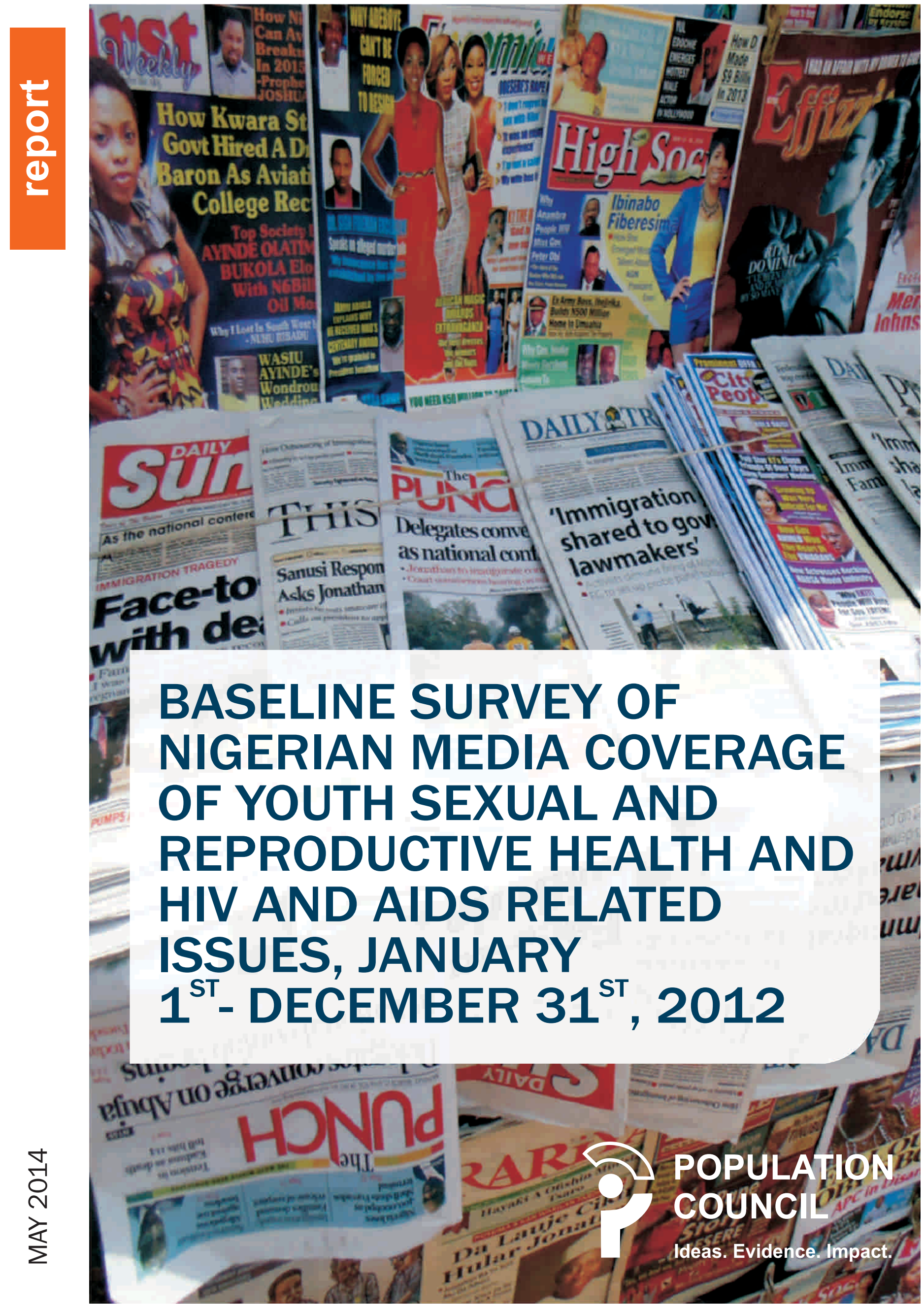




\title{
POPULATION
}

Ideas. Evidence. Impact.

The Population Council confronts critical health and development issues-from stopping the spread of HIV to improving reproductive health and ensuring that young people lead full and productive lives. Through biomedical, social science, and public health research in 50 countries, we work with our partners to deliver solutions that lead to more effective policies, programs, and technologies that improve lives around the world. Established in 1952 and headquartered in New York, the Council is a nongovernmental, nonprofit organization governed by an international board of trustees.

\author{
Population Council \\ House 4, No. 16B P.O.W. Mafemi Crescent \\ Utako District, Abuja \\ Nigeria \\ Tel: +234 92914878 \\ email:info.nigeria@popcouncil.org
}

popcouncil.org

Suggested citation: Population Council 2014. "Baseline survey of Nigerian media coverage of youth sexual and reproductive health and HIV and AIDS related issues, January $1^{\text {st }}$ - December $31^{\text {st }}, 2012 . "$ Abuja, Nigeria.

Cover photo by Raphael Nnakwe.

(C) 2014 The Population Council, Inc.

Any part of this publication may be photocopied without permission from the publisher provided that copies are distributed without charge and that full source citation is provided. The Population Council would appreciate receiving a copy of any material in which the text is used. 


\section{Acknowledgments}

This publication is based on research funded by the Ford Foundation and conducted by Mr.

Adewale Fatade of Media Support Centre, Lagos and his team of research assistants on behalf of the Population Council. We would like to thank Ford Foundation for their support of the project, Mr. Wale Fatade and his team for their hard work and efforts collecting and analyzing the data, and the key informants who gave graciously of their time and experience. We are grateful to all the Population Council staff who contributed to the design and implementation of the study and to the development of the publication. Finally, we dedicate this work to Nigerian youth and to the goal of HIV prevention and impact mitigation among youth in Nigeria and beyond.

\section{Study Team}

External Researcher

Adewale Fatade

Media Support Centre, Lagos

Research Assistants

Tajudeen Sulaiman

The NEWS Magazine, Abuja

Sogo Afolabi

Media Support Centre, Lagos

Tosin Akinola

Media Support Centre, Lagos

Population Council Team

Babatunde Ahonsi

Population Council, Abuja

Otibho Obianwu

Population Council, Abuja

Segun Sangowawa

Population Council, Abuja

George Eluwa

Population Council, Abuja 


\section{Table of Contents}

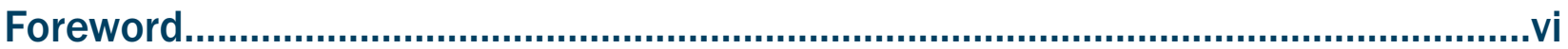

List of Abbreviations.............................................................................................1

Introduction and General Information on Current HIV/AIDS Situation in Nigeria.2

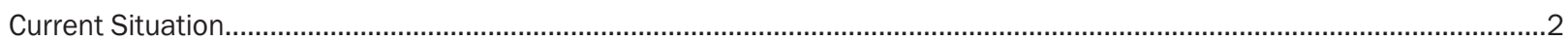

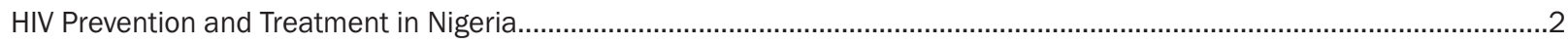

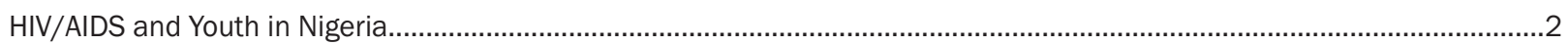

Role of the mass media in addressing HIV/AIDS challenges facing youth..................................................................... 4

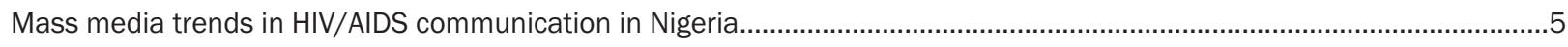

Mass media, adolescents, youth, and sexuality issues in Nigeria...................................................................................

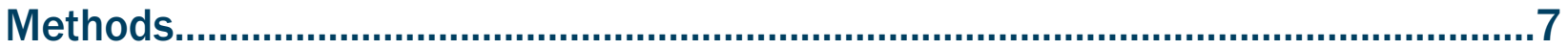

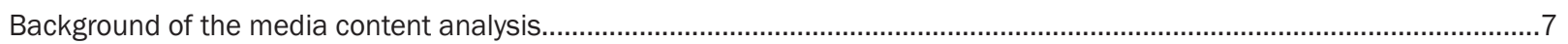

Selection of newspapers and the electronic medium............................................................................................

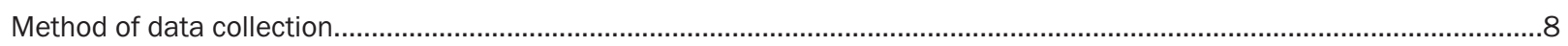

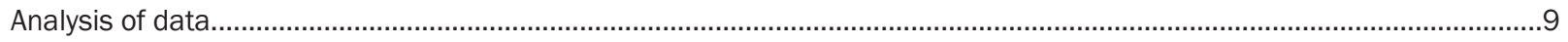

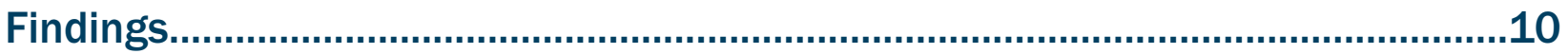

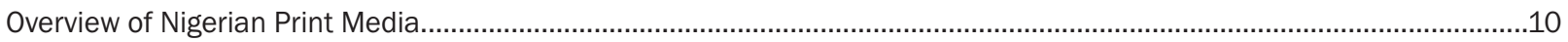

Brief information about the newspapers used for the content analysis...........................................................................10

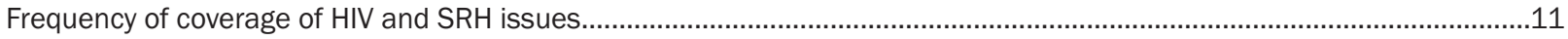

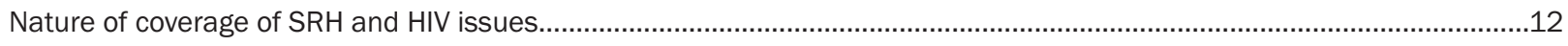

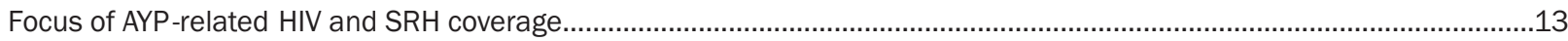

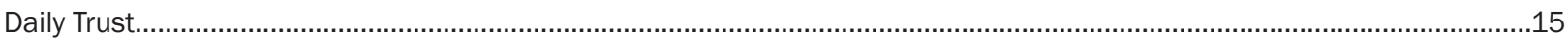

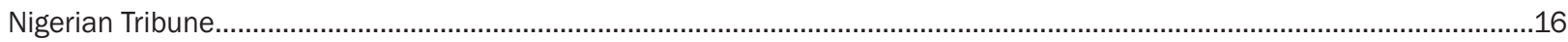

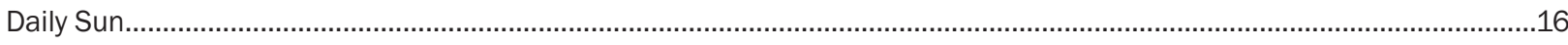

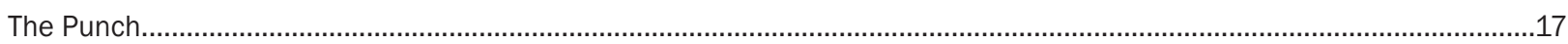

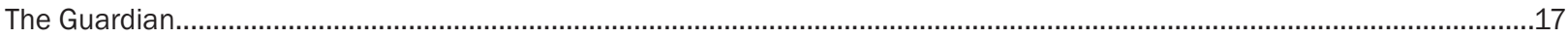

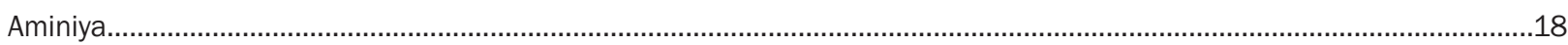

Ideological orientation of media treatment of AYP -related HIV and SRH issues..............................................................18

Linkage of Youth-related SRH and HIV/AIDS issues to broader health and development issues.........................................18

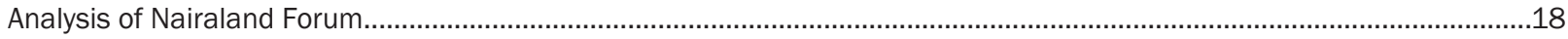

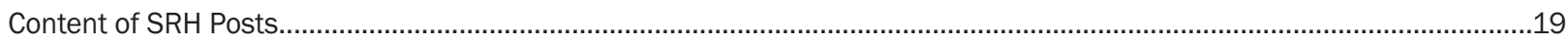

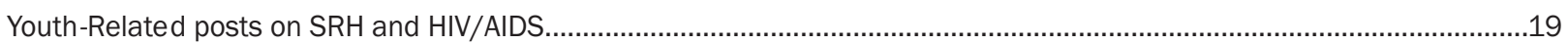

Key Informant Interviews......................................................................................32

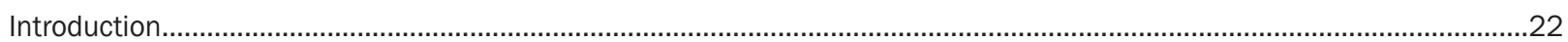

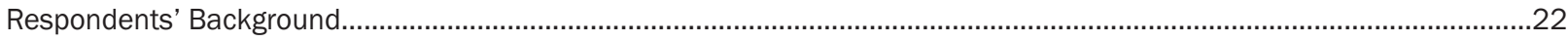

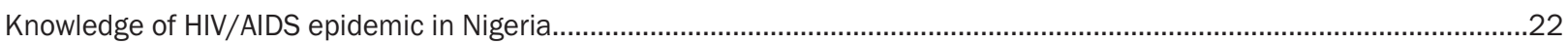


Knowledge of the HIV/AIDS epidemic and how it affects youth aged 15-24 in Nigeria.................................................................22

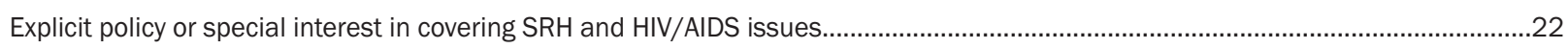

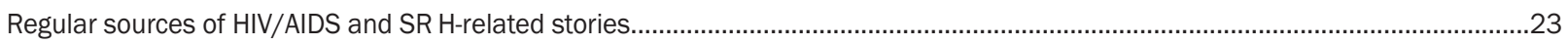

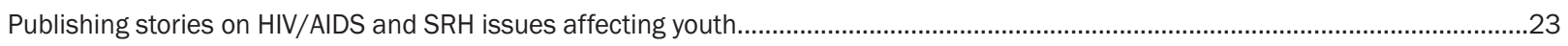

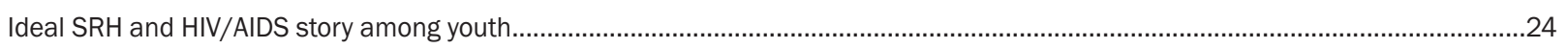

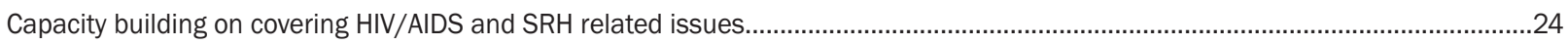

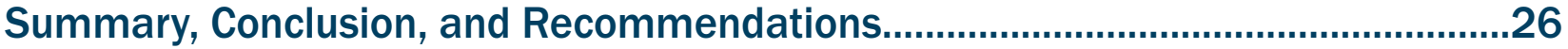

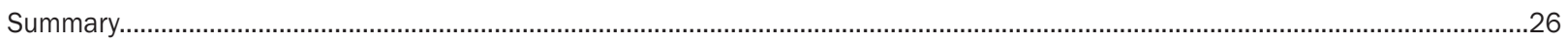

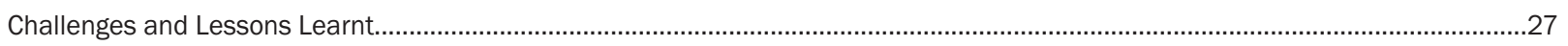

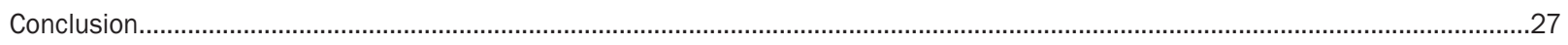

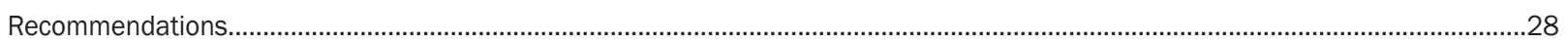

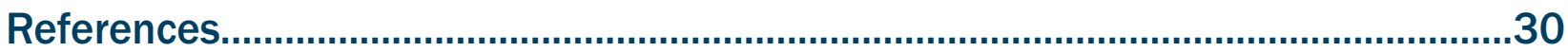

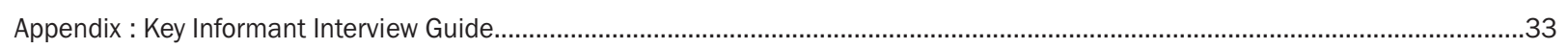




\section{Foreword}

As part of its goal to promote more informed public dialogue on youth vulnerabilities, responses to HIV/AIDS and positive changes in relevant policies and programs via an integrated set of learning and advocacy interventions at the state and national levels in Nigeria, the Population Council commissioned a study of the print and electronic media's coverage of HIV/AIDS and sexual and reproductive health (SRH) related issues among youth aged 15-24 years in Nigeria for the period January $1^{\text {st }}$ to December $31^{\text {st }} 2012$.

The study entailed a content analysis of four national and most widely circulating newspapers, Daily Trust, The Guardian, Daily Sun, The Punch and two regional newspapers, The Nigerian Tribune and Aminiya, a newspaper widely circulating in the northern part of Nigeria and printed in Hausa, one of the major languages spoken in the country. A content analysis of Nairaland, an online forum that is one of the most frequently visited social media sites in Nigeria, was similarly conducted for the same time period.

Additionally, key informant interviews were conducted with editors and health reporters/correspondents of the studied newspapers on factors that influence publishing articles on HIV/AIDS and SRH among adolescents and young people aged 15-24 years and sources of data used in the stories. They were also interviewed on what can be done to improve coverage of these issues.

The newspapers had a total of 746 stories on HIV/AIDS, sexuality, sexual health and sexual rights published in 2012. Some of these articles used stigmatizing language like "HIV victim", promoted anti-homosexual sentiments, or provided misinformation on HIV "cures." For the six newspapers, 50 of those stories focused on adolescents and young people aged 15-24 years, these represent $6.7 \%$ of the total articles published that related to HIV/AIDS and SRH.

The few AYP and SRH/HIV focused articles involved mostly sensational reporting of rape incidents. Most were not educational pieces that would inform youth and the general public. The ideological persuasion of the $\mathbf{5 0}$ stories was equally conservative as none of them was bold enough to advocate for adolescents and young people taking charge of their sexuality. Only one piece discussed teenagers and the morning after pill and this was sourced from a foreign publication while another was on how teenagers could remain healthy if they got pregnant.

This report shows that the level and quality of reportage on SRH and HIV/AIDS in relation to adolescents and young people aged 15-24 years is very low, in fact virtually nonexistent, among the newspapers analysed. There is, therefore, an urgent need to remedy this gap as the media still have a significant role to play in educating, informing, and advocating for change in people's attitudes and understanding of sexuality in Nigeria. 


\section{List of Abbreviations}

AIDS

APCON

AYP

HIV

NACA

NAN

NARHS

NDHS

NFVCB

NGO

$\mathrm{SRH}$

UNFPA

UNICEF

USAID

VVF

WHO
Acquired Immune Deficiency Syndrome

Advertising Practitioners Council of Nigeria

Adolescents and young people

Human Immuno-deficiency Virus

National Agency for the Control of AIDS

News Agency of Nigeria

National HIV/AIDS and Reproductive Health Survey

Nigeria Demographic Health Survey

Nigeria Film and Video Censors Board

Non-governmental organization

Sexual and reproductive health

United Nations Population Fund

United Nations Children's Fund

United States Agency for International Development

Vesicovaginal fistula

World Health Organization 


\section{Introduction and General Information on Current HIV/AIDS Situation in Nigeria}

\section{CURRENT SITUATION}

Nigeria has an estimated overall HIV prevalence of 3 percent with prevalence varying across sex, age, and geographic location. ${ }^{1}$ Although HIV prevalence is much lower in Nigeria than the hardest hit African countries, the size of Nigeria's population (over 162 million) means that there were an estimated 3.4 million people living with HIV in 2012. ${ }^{2,3}$ Worldwide, Nigeria has the second highest number of people living with HIV (PLHIV) with females constituting almost three-fifths (58.3\%) of PLHIV in Nigeria (about 1.72 million women and girls are infected with HIV). ${ }^{4,5}$ Approximately 210, 000 people died from AIDS in Nigeria in 2011 and the national life expectancy was 52 years ${ }^{.4,6}$

Heterosexual sex is the main mode of transmission in Nigeria. ${ }^{3}$ Citing the 2010 Mode of Transmission Study report, the President's Comprehensive Response Plan for HIV/AIDS In Nigeria 2013-2015 states that approximately 34.6\% of new HIV infections occur among couples considered as engaging in "low risk sex" while $23 \%$ occur among key populations. ${ }^{3}$ More than a third of all new infections were linked to female sex workers, their clients and partners, men who have sex with men and people who inject drugs and their partners. ${ }^{3}$ HIV transmission through unsafe blood accounts for the second largest source of HIV infection in Nigeria while mother to child transmission accounts for about $10 \%$ of new infections. ${ }^{3}$

Drivers of the HIV epidemic in Nigeria include low personal risk perception, multiple concurrent sexual partnerships, transactional and inter-generational sex, ineffective and inefficient services for sexually transmitted infections (STIs), and inadequate access to and poor quality of healthcare services. ${ }^{7}$ Additionally, gender inequity, poverty, and relatively high levels of HIV-related stigma and discrimination are important contributors to the spread of HIV.

\section{HIV PREVENTION AND TREATMENT IN NIGERIA}

The first two cases of HIV and AIDS in Nigeria were identified in 1985 and were reported at an international AIDS conference in $1986 .^{8}$ The following year, the National AIDS Advisory Committee was established followed by the National Expert Advisory Committee on AIDS (NEACA). The Nigerian government was slow to respond to rising rates of HIV transmission until 1991 when there was an attempt at assessing the HIV/AIDS situation in Nigeria. When antiretroviral drugs were introduced in the country in the early 1990s, they were only available to those who paid for them meaning only the wealthy were able to afford the treatment.

However, under the government of former President Olusegun Obasanjo, 1999-2007, HIV prevention, treatment and care was given greater attention and the President's Committee on AIDS and the National Action Committee on AIDS were created. Additionally in 2001, the government set up a three-year HIV/AIDS Emergency Action Plan (HEAP) and hosted the Organisation of African Unity's first African Summit on HIV/AIDS, Tuberculosis, and Other Related Infectious Diseases.

The government began an ambitious antiretroviral programme in 2001 which aimed to supply 10, 000 adults and 5, 000 children with antiretroviral drugs within one year. ${ }^{9}$ Despite improvements, gaps in treatment access still persists. At the end of December 2012, only 491,021 HIV positive persons out of an eligible population of 1.6 million were accessing ART. ${ }^{3}$

\section{HIV/AIDS AND YOUTH IN NIGERIA}

Nigerians aged 10-24 years account for approximately 31.6\% of Nigeria's large population and according to the 2012 National HIV/AIDS and Reproductive Health Survey (NARHS) the HIV 
prevalence among 15-19 year olds and 20-24 year olds was 2.9\% and 3.2\% respectively. ${ }^{1,2}$ Nigerian youth are exposed to sexual activity early in life. In the 2012 NARHS, the median age at first sex for respondents aged 15-24 years was 17 years for both males and females. ${ }^{1}$ Nigerian youth also report risky sexual practices. The prevalence of multiple sexual partnering among Nigerian youth is relatively high with reports ranging from $1.7 \%$ to $60 \% .{ }^{10-20}$ According to the preliminary report of the Nigeria Demographic and Health Survey 2013, 1.6\% of women and 8.9\% of men aged 20-24 years reported having $2+$ sexual partners in the past 12 months but only $41.9 \%$ of women and $51.3 \%$ of men in the same group reported condom use at last sex. ${ }^{10}$

Additionally, Nigerian youth have low levels of comprehensive HIV knowledge and HIV testing uptake. Less than a quarter (24.4\%) of young women and men aged 15-24 years had comprehensive HIV knowledge and only $7 \%$ and $15.2 \%$ of those aged 15-19 and 20-24 years, respectively, had ever had an HIV test and received their test results. ${ }^{1}$

Low risk perception is one of the drivers of the epidemic for the general Nigerian population and is unfortunately a common attitude among Nigerian youth as documented by several studies. A study of undergraduate students aged 15-25 years in Southwest Nigeria revealed that although $30.1 \%$ reported a past history of at least one STI, $60 \%$ had a history of multiple sexual partners and $40.7 \%$ reported a history of unprotected sexual intercourse in the month preceding the survey, only $15 \%$ of the students perceived themselves to be at moderate-to-high risk of contracting HIV infection in the future. ${ }^{17}$

Economic deprivation leads youth to engage in activities like transactional and commercial sex that undermine their ability to negotiate and adopt safer sex practices for fear of losing the economic benefits from such activities or relationships. According to the 2012 NARHS, $8.9 \%$ of females and $9.3 \%$ of males aged $15-19$ years and $7.5 \%$ of females and $7.9 \%$ aged $20-24$ years had ever had sex in exchange for gifts or favours. ${ }^{1}$

Poverty can also induce youth especially females to engage in intergenerational sex which is often interwoven with transactional sex further increasing their SRH vulnerabilities. In a survey by Odu et al, 39.3\% of tertiary institution students revealed having had significantly older ("sugardaddy/mummy") sexual partners and over three-quarters (77.4\%) of those respondents expected some financial or material rewards from those relationships (2008). ${ }^{16}$ In the situation of female youth, economic pressures, inequitable gender norms and the increased likelihood of exposure to HIV/STIs (their older partners are more likely to have been exposed to these infections as they are more sexually experienced) is a potent mixture for increased SRH vulnerability. In the 2008 NDHS, 11\% of women aged 15-19 years who engaged in "higher-risk sexual intercourse" (with a non-marital, non-cohabitating partner) in the 12 months preceding the survey, endorsed having had higher risk sexual intercourse with a man ten or more years older than them. ${ }^{21}$

Early marriage of girls to older men in some parts of the country is also an issue. In a setting where male pre-marital and multiple sexual partnerships are culturally sanctioned, their older spouses are more likely to have come into contact with HIV/AIDS and other STIs putting girl brides at risk. ${ }^{22}$ According to the 2008 NDHS, about one-quarter of married women aged 15-19 years $(26 \%)$ and $20-24$ years $(25.7 \%)$ reported being in polygynous marriages yet only $9.5 \%$ of ever married women aged 15-24 years used a condom at first sexual intercourse compared to $23.7 \%$ of their never married age peers. ${ }^{21}$ Female youth who marry at an early age have less knowledge about HIV and AIDS than their unmarried counterparts, and are more likely to believe that they are at low-risk for becoming infected with $\mathrm{HIV}^{23}$

Despite evidence of the HIV/AIDS and SRH vulnerabilities of Nigerian youth, youth especially girls and young women remain a neglected sub-population in the response to HIV. Current funding mechanisms geared towards strengthening health care facilities and community programmes to 
provide HIV prevention interventions are often not youth-friendly in design and implementation. Youth, therefore, fail to access these services which further worsen their vulnerability to HIV/AIDS as they are ill-informed to adequately deal with their sexual and reproductive health needs.

Disseminating information on HIV/AIDS and sexual health to young people in Nigeria remains a sensitive issue. Sex is traditionally a very private subject and its discussion especially with adolescents is often seen as inappropriate. Religious beliefs can also be a barrier in providing sex education for youth. Oshi and Nakalema discovered that while primary school teachers have a reasonably high knowledge of the modes of HIV transmission, the behavioural risk factors and modes of transmission, they are, however, reluctant to teach this because of socio-cultural and religious factors, lack of teacher training in delivery of sex education as well as poor motivation. ${ }^{24}$ Only $31.9 \%$ and $35.8 \%$ of respondents surveyed in the 2012 NARHS reported discussing sexual relationships with their sons/male wards and daughters/female wards respectively. ${ }^{1}$

\section{ROLE OF THE MASS MEDIA IN ADDRESSING HIV/AIDS CHALLENGES FACING YOUTH}

Mass media have the capacity to inform and educate people. They can also provide the foundation for positive behavior change. Over the decades, HIV prevention programmes around the world have used mass media campaigns to increase testing and improve people's knowledge of their HIV status. ${ }^{25}$ In Nigeria, there have been several intervention campaigns using the mass media in disseminating information about the disease. There have been many programmes on both radio and television stations geared towards helping people make informed decisions about sexuality issues and HIV. A way of achieving this has been through the placement of advertisements on both radio and television. These adverts are packaged in ways that are easy to understand; using local languages especially pidgin english which is widely spoken among Nigerians and are geared towards changing HIV-related attitudes and behaviours.

Anthony Utulu (2011) posits that "the media is believed to be the most appropriate channel through which the far-flung heterogeneous people within the country (Nigeria) could be reached as quickly as possible and subsequently informed and/or educated about the disease and what is needed to prevent, curb, and hopefully totally overcome it. Thus, the importance of the mass communication media is obvious." ${ }^{26}$

In analyzing the impact of the mass media on youth sexual and reproductive health, HIV and AIDS issues and policy response in Nigeria, two mass media theories are relevant. The first is the agenda-setting theory which suggests that the media does not merely disseminate information to its audience but sets the public agenda as media emphasis on an issue influences the audience to also view the issue as important. ${ }^{27}$ The second is the framing theory which is related to the agenda setting theory.

A frame refers to the way the media organizes and presents an issue/event it is covering and the way the audience interprets this coverage. ${ }^{28}$ The framing theory suggests that the way or the frame in which the media presents information to an audience can influence the audience's beliefs, attitudes, and behaviors by connecting a particular meaning or interpretation to an issue. The framing theory refers to the media's ability to persuade its audiences to accept one meaning of a concept over another. The media not only has the power to tell audiences what issues to think about but also has the potential to tell them how and what to think about said issues.

The Nigerian media has played this role of agenda setting in terms of HIV/AIDS issues ever since the first HIV case was identified in the country. The use of the mass media in creating awareness about HIV/AIDS has helped many Nigerians to learn about the disease and how to prevent its spread. ${ }^{29}$ In doing this, the mass media are seen as setting agenda on the issue. In other words, transmitting messages about the issue through their channels enables them play an agenda- 
setting role. The frequency of transmission of media content would be important to this role. ${ }^{29}$

Additionally the media has, to a large extent, succeeded in making Nigerians talk about HIV/AIDS and has also helped in the fight against the spread of the disease and stigmatization of those living with it. The case of Gloria Asuquo, a PLWHA who was diagnosed with HIV in 1999 at 12 years old is an example of what the Nigerian media can do in terms of agenda setting. ${ }^{30}$ The story of her court case was followed faithfully until she got judgment in 2012 as reported in the Daily Trust of September 4, 2012.

Due to the various issues competing for attention daily in Nigerian newsrooms, what the journalists choose to feature and the position accorded such issues depend on their individual judgment. This was observed by Akpabio (2005) who stated that "there can be no doubt about the fact that there is more news everyday than the media can possibly accommodate. It is equally true that there could be a dearth of news so much so that what on a good day would not even merit a mention could make headlines. However, because the former scenario is the reality, media gatekeepers using news judgment criteria pick and choose what constitutes the day's news." ${ }^{31}$

Adesegun Fatusi and Akin Jimoh (2006) posit, "They (mass media) can also affect people's perception of social norms, which in turn support people's efforts to change behavior. The media can also play a powerful advocacy role for policies that support sustainable behavior change at the population level. Furthermore, radio and television are important channels for "edutainment" approaches such as soap opera and drama series, which are powerful catalysts for behavior change." ${ }^{29}$

Findings from the NARHS 2012 attest to the importance of mass media in the HIV/AIDS sector. The survey showed that most Nigerians consider all forms of mass media acceptable for reaching the populace with information about HIV/AIDS and family planning. ${ }^{1}$ Radio was the most accepted (76.9\%), followed by television (69.5\%), and the print media (62.8\%). The same survey found that the most mentioned source of information on condom use was radio (83\%) followed by television $(57 \%)$ with health workers and clinics at $41.5 \%$ and $25.3 \%$, respectively.

\section{MASS MEDIA TRENDS IN HIV/AIDS COMMUNICATION IN NIGERIA}

Most HIV/AIDS stories in Nigeria in the early years of the epidemic were not considered news worthy enough to make it to the front page in print or lead items in electronic media. ${ }^{29}$ Editors then did not have a full grasp of what the epidemic entails and with stories on politics, business, sports and fashion, general science or medical stories did not command the kind of attention they deserved.

There were sensational headlines like "Another AIDS victim is dead"; "Call girls spread AIDS"; "New killer sexual disease discovered" which propagated the idea of HIV infection as a death sentence. ${ }^{29}$ Later, there were also false stories of miracle cures and discovery of drugs that supposedly cure HIV. Initial coverage also included reportage of workshops and seminars, which were sometimes too technical for the average reader or listener to understand. Two decades after, with trainings and capacity building programmes for journalists, coverage has improved with fewer stigmatizing stories. Nowadays it is not uncommon for HIV/AIDS stories to make the front page or be the lead on radio and television news and not just on World AIDS Day.

\section{MASS MEDIA, ADOLESCENTS, YOUTH, AND SEXUALITY ISSUES IN NIGERIA}

Radio and television seem to be at the forefront of reaching young people on sexuality issues. UNFPA developed and produced a television series on adolescent reproductive health titled "I Need to Know" in 1999. A second season production commenced in 2003 and has been extended in local languages to over 20 television and 15 radio stations across Nigeria. This 
second season focused on HIV/AIDS information. The UNFPA says that an impact survey conducted in 2000 indicated that the drama is used by families as a tool for parent-child communication and has contributed to breaking the silence on adolescent sexual and reproductive health issues. ${ }^{32}$

There are other drama series like Wetin Dey that also ran on television stations in the country but targeted the general population and not just adolescents and youth. ${ }^{33}$ It was produced by BBC Media Action (formerly known as the BBC World Service Trust) to transmit messages on HIV/AIDS, sexuality, and reproductive health. BBC Media Action has also implemented two radio shows focused on educating young people aged 15-24 on HIV and AIDS, Flava (broadcast in Pidgin English) and Ya Take Ne (the Hausa-language sister). ${ }^{34}$ The weekly, 30-minute radio shows were both designed to appeal to both sexes and highly successful and popular. Reach survey figures collected in 2008 report Flava reaching 19 million and Ya Take Ne 5.7 million 15-24 year olds. According to BBC Media Action, a post-broadcast assessment study in 2011 revealed that the target audience had learned important lessons from listening to the shows with "the most prominent related to HIV prevention, specifically the use of condoms and the value of not having multiple sexual partners at the same time.."14 


\section{Methods}

\section{BACKGROUND OF THE MEDIA CONTENT ANALYSIS}

The Population Council is currently implementing a Ford Foundation funded project with a goal to promote more informed public dialogue on youth vulnerabilities, responses to HIV/AIDS and positive changes in relevant policies and programmes via an integrated set of learning and advocacy interventions at the state and national levels in Nigeria.

A key project activity is a comprehensive print and social media content analysis of HIV/AIDS, sexual and reproductive health issues specifically for adolescents and young people aged 1524 years in Nigeria for the period January $1^{\text {st }}$ to December $31^{\text {st }} 2012$. This activity also included key informant interviews with editors/health columnists of the researched print media on factors that influence publishing articles on HIV/AIDS and SRH among adolescents and young people aged 15-24 years, sources of data used in the articles, and what can be done to improve the coverage of youth and HIV-related topics. The analysis aimed to identify the following:

a. How frequently are HIV/AIDS, SRH and sexual rights issues among adolescents and young people (AYP) featured in the press?

b. What aspects of HIV/AIDS, SRH and sexual rights among AYP are presented?

c. How much HIV/AIDS, SRH and sexual rights information on AYP is provided?

d. Where/when is HIV/AIDS, SRH and sexual rights among AYP featured in the press?

e. What is the ideological background of the media presenting the AYP related HIV/AIDS, $\mathrm{SRH}$ and sexual rights information? What are the editorial guidelines of the relevant media? Are they different from other media?

\section{SELECTION OF NEWSPAPERS AND THE ELECTRONIC MEDIUM}

The news papers used for this study were Daily Trust, The Guardian, Daily Sun, The Punch, Nigerian Tribune and Aminiya, a Hausa language news paper published monthly by the Daily Trust. The Daily Trust, Guardian and Daily Sun and The Punch were chosen to represent national news papers while the Tribune and Aminiya were selected as southern and northern regional news papers respectively.

Accurate news paper circulation figures are difficult to obtain in Nigeria, as there are no reliable or credible sources. Abdulraheem et al (2012) quote Ekeng (2010) as revealing that The Punch, as the number one selling national daily, circulates 34,264 copies, The Sun was ranked third with 25,632 unit sales and the Guardian was 5th with 25,222 daily sales.35 Daily Trust, the most popular newspaper up North has 11,672 daily unit sales and the Tribune has 8,314 daily sales. It is commonly thought that news papers and news magazines are not open about their circulation figures while advertisers source their own data based on what the advertising agencies supply.

Classifying the Tribune, as a regional newspaper may be contentious as anecdotally there is no substantial difference between its circulation and the other "national" newspapers used in this analysis but the public perception of the Tribune as an unofficial mouthpiece of the Yoruba, one of the many ethnic groups in Nigeria may justify its classification. Aminiya perfectly fits this description, as it is a publication targeted mainly at the Hausa speaking population of Nigeria and therefore classified as a regional paper. It is also a newspaper printed in a widely spoken northern Nigerian language. 
The electronic medium used was Nairaland.com, the most popular online discussion forum utilized by Nigerians with over 1 million users. It is not a news site and its content is memberdriven. Typically, members post on a wide range of issues of interest to them with other members free to comment or discuss them. Sometimes posts are in the form of question and answer sessions by experts or other professionals. Although, Nairaland.com does not qualify as a news site run by professional journalists, the data gleaned from it can be used to assess the public dialogue around issues pertinent to this content analysis.

\section{METHOD OF DATA COLLECTION}

To facilitate the collection and analysis of the data from the newspapers, we took the following steps:

a. Visits to the publishers of the newspapers identified for the study. Even though only six newspapers were analyzed, nearly a dozen newspapers and news magazine libraries were visited in Lagos, Ibadan, and Abuja to obtain the material for the study. We used The NEWS Magazine, The Guardian, This Day, The Nation, Tribune, Daily Trust, TELL, The Punch, Sun, and private libraries to access the relevant copies. None of these sources had a digital library. The Daily Trust did not have all 52 copies of Aminiya for 2012 so we had to rely on alternative sources to obtain the November and December editions.

b. Since only two of the newspapers have electronic archives of their past publications, the physical copies were read thoroughly from front page to back page to identify stories on HIV/AIDS and sexual and reproductive health before identifying those that were particularly targeted at adolescents and young people aged $15-24$ years. A total of 1,882 copies of these newspapers were analyzed since 2012 was a leap year and each newspaper was published for 366 days. Fifty-two copies of Aminiya - since it is published weekly- were examined and analyzed by another researcher who speaks and understands the nuances of Hausa language.

After identifying these stories, the online archives were used to trace them for further analysis. Some were available but most were not, and the team had to rely on the hard copies to make notes on each story. None of the newspaper libraries visited had a functioning photocopier and the materials were not allowed to be taken outside the libraries so researchers relied solely on notes taken during their visits to the libraries.

c. An organizing frame was developed for further analysis of the stories identified and involved answering the following questions:

- Does the particular edition have an item focused on SRH/HIV? - Yes or No

- $\quad$ And if Yes, is this SRH/HIV item relevant to adolescents and young people $(\mathrm{AYP})$ ? - Yes or No

- If YES, what type of item is it - brief, feature, editorial, opinion article, and others?

- Some description of the content in terms of its thematic or issue focus, evidential base, perspective/slant and source

d. A total of 302 web pages were analyzed for Nairaland.com for postings on health issues for 2012 while 293 postings were on HIV/AIDS, sexuality and reproductive health.

e. The editors and health correspondents of five of the six study newspapers used for 
this study were also interviewed. (See the appendix for the questions asked during the interviews). The Daily Trust health editor was interviewed and offered some insights on their operations and what shapes their attitude to HIV/AIDS and sexual and reproductive health reporting.

\section{ANALYSIS OF DATA}

The articles and findings were entered in an excel sheet and analyzed using the organizing frame. 


\section{Findings}

\section{OVERVIEW OF NIGERIAN PRINT MEDIA}

Nigerian newspapers have evolved over time from their early days when they focused on "adversarial journalism" and served as mouthpieces of political parties fighting for independence from the British colonialists to independent newspapers not owned by any political party. Though they do not shy away from taking sides with political parties from time to time, they all profess to be independent even when politicians of different political persuasions own some newspapers. The majority of newspapers published in Nigeria are based in Lagos, the former capital city and now the major commercial city. This has given rise to the so-called Lagos-Ibadan media axis, which refers to those newspapers published in Lagos and Ibadan.

On an ideological spectrum, Nigerian newspapers are still conservative and refrain from treating sexuality issues openly on their pages. For example, none of them has ever expressed support for abortion even though they may support other family planning methods. Even The Guardian, one of the newspapers used for this study, that calls itself a liberal newspaper, never did so in any of the 366 editions examined. Furthermore, tabloids like Daily Sun that report in the classical tabloid sense never advocated for radical changes in the choices available to adolescents and young people in terms of their sexual and reproductive health.

Daily Trust and Aminiya, a Hausa language weekly newspaper published by the same organization reflect the fact that they are located in the northern part of the country and primarily targeted at a largely conservative northern audience. For instance, an editorial published by Aminiya in its Vol. 6 , January $13-19,2012$ edition raises alarm on the high rate of promiscuity, rape, and prostitution among young girls. It also cautions against indecency/pornography believing that these upset decency in society and further calls on the film watchdog, National Film and Video Censors Board (NFVCB) to take care of its responsibility, and Advertising Practitioners Council of Nigeria (APCON) - the body that regulates adverts in the country, to impress on members to beware of films "that negate cultural norms of our society." The editorial never mentioned sexuality education or any other form of intervention that could be made available to the young girls apart from religious and moral persuasion.

\section{BRIEF INFORMATION ABOUT THE NEWSPAPERS USED FOR THE CONTENT ANALYSIS}

The Weekly Trust was established in March 1998 and the Daily Trust was launched in January 2001. Seen largely as a voice of the northern part of Nigeria, the Daily Trust is the largest circulating newspaper in that part of the country and its management claim that "the newspapers ranks among the top seven in Nigeria in advertising revenue." Daily Trust can be described as conservative and nowhere is this more evident than in its coverage of sexual and reproductive health.

The Nigerian Tribune is the oldest surviving private newspaper in Nigeria. Obafemi Awolowo, a lawyer and politician, established it in November 1949. It is viewed as an unofficial mouthpiece of the Yoruba, one of the many ethnic groups in Nigeria. Though widely circulated across the country, it was identified as a "regional" newspaper for the purpose of this study. The newspaper publishes three editions (Nigerian Tribune, Saturday Tribune and Sunday Tribune) but for the purpose of this content analysis, the three editions are treated as one. Stories included news, interviews, features, and an "Agony Aunt" column. The "Agony Aunt" column involves readers writing to a person who gives advice on a wide range of issues but mostly on relationships. It is called "Relationships".

The Daily Sun says it practices journalism in the classical tabloid sense. The newspaper 
commenced operations on January $18^{\text {th }}, 2003$ with the publication of a weekly and on June 16, 2003 , it went daily. Its mission is to "practice journalism in the classical tradition of presenting the news and features in an exciting style, with impact, objectivity and appeal that generate returns to all stakeholders: the society, the investors and the practitioners." The titles it offers are: Daily Sun, Saturday Sun, and Sunday Sun, and again for the purpose of this content analysis, they were treated as one though they have different editors.

The Punch newspaper was founded by James Aboderin, an accountant, and Sam Amuka, a journalist, who was a columnist with the Daily Times. In November 1976, they started printing the daily edition with the weekly and daily editions designed to favour a friendlier political approach to news reporting, combining footage of social events with everyday political news. Again, the newspaper has three different titles, The Punch, which is the daily edition, Saturday Punch, and Sunday Punch.

The Guardian, established in 1983 prides itself as "The flagship" of Nigerian journalism and sees itself as a liberal newspaper. The paper has three titles in its stable as well: The Guardian, The Guardian on Saturday, and The Guardian on Sunday each with a different editor.

Aminiya is a weekly, Hausa language newspaper published by the Daily Trust.

\section{FREQUENCY OF COVERAGE OF HIV AND SRH ISSUES}

All the newspapers analyzed have specific days in the week devoted to science and health issues which are often combined together. Aminiya being a weekly newspaper only publishes as it deems fit because there are no specific pages devoted to health issues at regular periods. It, however, published a total of 28 stories that focused on sexual and reproductive health, HIV and AIDS out of the 52 editions for 2012 with one being an editorial related to AYP. All the stories were published in twenty (20) editions during the year under review.

Daily Trust usually publishes stories on health issues on Tuesdays and also has a weekly "Health Advice" column written by a public health physician who covers different topics on those days. The paper wrote three editorials on SRH and HIV issues in 2012 on January $25^{\text {th }}$, August $23^{\text {rd }}$, and September $28^{\text {th }}$. The paper published 132 stories on SRH and HIV/AIDS with twenty four (24) focused on youth.

Nigerian Tribune dedicates Thursdays to publishing stories on health issues. Sometimes, stories on SRH and HIV/AIDS make it to other pages of the paper as news or brief items and short stories that are usually no longer than three paragraphs maximum. The paper published 139 stories on SRH and HIV/AIDS in 2012 with nine (9) specifically on youth. The paper wrote an editorial on December $28^{\text {th }}$ about a secondary school principal that conducted a "virginity" test on students in Ogun State without parental consent.

Daily Sun equally has a health and science dedicated day, Thursdays, where a majority of its stories on SRH and HIV/AIDS are typically published. It published 101 stories on SRH and HIV/AIDS with eleven (11) dedicated to issues affecting youth. The paper did not write any editorial on SRH and HIV/AIDS.

The Punch usually publishes stories on health on Wednesdays and most of the 96 stories published on SRH and HIV/AIDS were published on these days. Four (4) of these stories were on issues affecting youth. Sometimes, stories on SRH and HIV/AIDS were published in the news pages of the newspaper. Most of these stories were reports of workshops and events such as the World AIDS Day, usually observed on December $1^{\text {st }}$ every year.

The Guardian dedicates Thursdays for stories on science and health. It also has a section titled "Natural Health." The Guardian had twenty (20) opinion articles on SRH and HIV/AIDS in the 
period under review but no editorial. It published 247 stories on SRH and HIV/AIDS in 2012 with six (6) related to youth.

For all of the newspapers, the number of pages devoted to science and health are not fixed but they usually range between a minimum of two pages and a maximum of 10 pages. None has a section devoted to SRH and HIV/AIDS specifically.

\section{NATURE OF COVERAGE OF SRH AND HIV ISSUES}

Coverage has improved from the early days of coverage of SRH and HIV/AIDS issues in the mid 1990s but there is still stigmatizing coverage though reports are more lucid and detailed than what was available fifteen to twenty years ago. ${ }^{31}$ A significant number of the 746 stories published on SRH and HIV/AIDS in the six newspapers were sourced from events like workshops and occasions. The stories were presented in feature articles, news pieces, interviews, editorials and comments and briefs, short pieces usually between two and four paragraphs.

Sometimes journalists conduct interviews in sourcing their stories and at other times, they sourced them from local and foreign wires like the News Agency of Nigeria (NAN), Agence France Presse (AFP), Reuters, and the New York Times News Services. Only one story, Not just in the north, VVF (vesico-vaginal fistula) also occurs in the south, published on January $4^{\text {th }}$ in the Daily Trust was an investigative piece.

Focus on official figures: Journalists still show a fixation with reporting figures routinely given by heads of governmental agencies in the health and development sectors, foreigners, and elected officials without further interrogation or follow-up stories that would properly situate these figures in their context and expand the knowledge base of their audience in regards to the topic covered. Examples include: Nigeria to spend N5.41 billion on reproductive health items; US doles out \$24million to fight AIDS; 70, 000 newly born babies are HIV positive says NACA; 3 million HIV carriers diagnosed in 2011; 92, 000 Enugu residents live with HIV; 13, 680 prostitutes operate in Lagos every night.

Claims of cures: Daily Sun and Tribune published stories of claims of cure for HIV/AIDS. Sun had stories like Holistic remedy for HIV/AIDS, Man claims he has cure for HIV; Are you suffering from HIV/AIDS come and be healed with herbs; God gave me therapy for HIV/AIDS. Tribune published a story titled, Untold story of how church healed nurse of HIV.

Use of stigmatizing language: The newspapers continue to use stigmatizing words in their coverage as seen in The Sun's Are you suffering from HIV/AIDS. Other headlines that are stigmainducing include Hepatitis $B$ is deadlier than HIV, Asthma is as deadly as AIDS, both from The Punch while Daily Trust has Justice for HIV victim and Group alleges neglect of rural HIV/AIDS victims. Only Guardian had no stigmatizing words in its headlines or in the body of all the stories analyzed.

Limited coverage of sexual orientation and gender identity-related issues: Homosexuality was also treated in the newspapers as four newspapers Daily Trust, Tribune, The Guardian, and Sun had seven (7) related stories. Daily Trust had an interview with a senator, We've no apology for criminalizing same sex marriage - Senator Odunsi, while The Guardian had Lawyer sues Jonathan, Senate over gays' rights which was about a lawyer who went to court protesting against the bill prohibiting same sex marriage in the country. Tribune had Most homosexual men probably have AIDS, an interview with an actress titled Me gay, never I love men a lot, Most people think I'm gay and My gay husband wants me out published under the agony aunt column of the paper. Sun had Gay marriage versus gay tendencies, a story published in a column that teaches readers how to suppress homosexual tendencies. 
Use of highly technical language when reporting scientific research: There were also stories that read more like scientific journal articles rather than newspaper articles. Such include Toning the endometrium adds value to spermatozoa in Punch, while Guardian had African study associates exposure to micronutrients pre-pregnancy with gene modifications. Reports of scientific research on HIV/AIDS were mostly from foreign sources with nothing on work done by Nigerian researchers in the country. There were, however, reports of studies by Nigerians on SRH issues.

Relatively high coverage of sexual violence: All the newspapers had many stories on sexual violence (mostly rape) often based on police and court case reports (Daily Trust - 16; Nigerian Tribune - 20; Punch - 13; Sun - 27; Guardian - 5; Aminiya - 2). The stories on sexual violence accounted for about $11 \%$ of SRH/HIV stories reported for the year. The newspapers published stories on family planning and the contraception options available for married people. The way such issues were treated for youth will be addressed in a subsequent section.

\section{FOCUS OF AYP-RELATED HIV AND SRH COVERAGE}

The youth-related HIV and SRH coverage focused more on items written solely for news alone as opposed to items that are features, investigative reports, and interviews. As seen in the list below, a lot of the pieces published were news items. For Daily Trust, there were seven (7) news items, which provided information, as given by the subjects identified in the stories. There was no followup to such stories like Girl, 16, arraigned over death of own baby; Driver rapes 20-year old passenger for three days; HIV/AIDS: Youth canvass for quick passage of anti-stigma bill, Man, 24, in court over rape; Victim's father forgives alleged rapist; Minister seeks care for HIV/AIDS infected kids; US promotes HIV/AIDS free-generation songs contest either as news items or features examining in detail some of the emerging issues in the stories.

There were stories that sought to inform youth on issues like child-marriage, girl child education, preparing girls for their first menstruation experience, and the HIV information telephone helpline for young people in Abuja, the Federal Capital Territory (FCT). A story equally talked about the means of transmission of HIV/AIDS and why youth should "spread the news not the virus." An article titled Married adolescents in Nigeria, did not treat the subject in detail but merely provided a report of happenings at a workshop. 


\begin{tabular}{ll} 
Type of news item & $\begin{array}{l}\text { Mostly news items, few features, investigative reports, and } \\
\text { interviews }\end{array}$ \\
Subject area focus & $\begin{array}{l}\text { Largely sensational reporting of rape incidents and some coverage } \\
\text { of HIV/AIDS and AYP, child marriage, sexual abuse, teenage } \\
\text { pregnancy; one article each on contraception and abortion; few } \\
\text { educational articles that would inform AYP } \\
\text { Conservative reporting with no item encouraging or providing } \\
\text { information that would enable AYP to take charge of their sexuality; }\end{array}$ \\
\hline
\end{tabular}

Tribune had five (5) news items with two on rape incidents, one on the opening of a centre donated by a mobile telephone company for voluntary counseling and testing at a university, the delivery of a premature baby by a 17-year old and a "virginity-test" conducted by a secondary school principal in Ogun State for girls at the school. The last item attracted an editorial by the paper where the action was condemned. There was a feature story on pregnant teenagers' health that provided information on nutrition and health requirements for teenagers who might be pregnant.

Sun had eleven (11) news items with eight (8) on rape. The remaining three (3) were a report on an undergraduate who wrote a book on marriage and HIV/AIDS, an interview of a 21-year old who said he became a reproductive health activist because of his sister's death and a true-life account of a lady who claimed her father's friend wanted to have sex with her before helping her secure a job.

Punch published four (4) youth-related HIV and SRH stories with two (2) as news items. One was a report of how robbers attacked a luxury bus of students returning to their school on the LagosBenin expressway and allegedly raped the girls on the bus; the other was on the "virginity test" cited earlier. Two feature stories on educating the adolescent girl on sexuality and a New York Times syndicated piece on teenagers and the morning after pill were also published. The piece on adolescent girls and sexuality was written by the executive director of a girl-focused nongovernmental organization discussed the negative effects of early births on adolescent girls and advocated for "broad and continuous sexuality education" and "access to full range of SRH services" without going into the specifics of these ideas. The Times piece discussed the result of a study on how teenagers access the morning after pill in the United States.

Guardian had six (6) youth-related HIV/AIDS and SRH stories for 2012. Two were news reports of rape incidents while one was an opinion piece by a rape survivor (name not disclosed), who said that the trauma of rape is for life and the fourth was a column on how long a woman should remain a virgin. The story promoted abstinence till marriage. The remaining two were on a group warning parents and girls against abortion and how young people bear the highest burden of HIV/AIDS.

As previously mentioned, Aminiya published only one pertinent article during the relevant time period, an editorial raising the alarm on the high rate of promiscuity, rape, and prostitution among young girls. 
Table 2: No. of stories on SRH and HIV/AIDS published in 2012 across the different newspapers

\begin{tabular}{llll}
\hline Newspaper & $\begin{array}{l}\text { Total stories in } \\
2012 \text { on sexual } \\
\text { and reproductive } \\
\text { health and } \\
\text { HIV/AIDS }\end{array}$ & AYP-related & $\begin{array}{l}\text { Percentage of total } \\
\text { stories }\end{array}$ \\
\hline Daily Trust & 132 & 19 & 14.39 \\
Daily Sun & 101 & 11 & 10.89 \\
Nigerian Tribune & 139 & 9 & 6.47 \\
The Punch & 99 & 4 & 4.04 \\
The Guardian & 247 & 6 & 2.43 \\
Aminiya & 28 & 1 & 3.57 \\
Total & 746 & 50 & 6.70 \\
\hline
\end{tabular}

\section{Daily Trust}

For Daily Trust only 19 (14.39\%) of the 132 stories on sexual and reproductive health and HIV/AIDS focused on youth.

The stories that directly focused on adolescents and young people were:

- Combating female genital mutilation on February $9^{\text {th }}$, a news story

- Girl, 16, arraigned over death of own baby on February $29^{\text {th }}$, the reporter did not expand further to explore possible related topics like teenage pregnancy, post-partum depression, etc.

- Police arraign man, 21, for alleged rape of 2-yr old girl, on March $21^{\text {st }}$, a news story

- Driver rapes 20-year old passenger for three days on March 29 ${ }^{\text {th }}$, a brief story that did not mention the name of the alleged rapist

- Preparing your daughter for her first menstruation on April $6^{\text {th }}$, a feature story

- HIV info line opens on toll-free 6222 targeting millions of young people in Abuja, brief news item on May $1^{\text {st }}$

- Our adolescents and health risk, a feature story on May $1^{\text {st }}$

- HIV/AIDS: Spreading the news not the virus - a feature story that targeted adolescents and young people on May 8th

- How to prevent your children from sexual abuse- an opinion article written by a staff member on June $22^{\text {nd }}$

- HIV/AIDS: Youth canvass for quick passage of anti-stigma bill, news published on August $28^{\text {th }}$

- Stigmatization, discrimination almost ruined my life (Interview with Gloria Asuquo, a PLWHA) published on September $4^{\text {th }}$. She was 12 years old in 1999 when diagnosed with HIV. 
- Man, 24, in court over rape of 8-yr old - news item on September $13^{\text {th }}$

- Sex trafficking swells - UNODC - a news item on September $28^{\text {th }}$

- The girl child, education and early marriage - feature story on October $19^{\text {th }}$

- Not till I am 18 - Feature story on early marriage of girls on October $30^{\text {th }}$

- Victim's father forgives alleged rapist (24- year old rapist/13-year old victim) - News item on November $2^{\text {nd }}$

- Married adolescents in Nigeria - Workshop report by a columnist on November $15^{\text {th }}$

- $\quad$ Minister seeks care for HIV/AIDS infected kids - news item, December $3^{\text {rd }}$

- US promotes HIV/AIDS free-generation songs contest - news item, December $3^{\text {rd }}$

\section{Nigerian Tribune}

There were only nine (9) stories on SRH and HIV/AIDS that directly related to youth aged 15-24, out of 139 stories on SRH and HIV in general which represents $6.47 \%$ of the total stories analyzed.

The stories were:

- Safeguarding pregnant teenagers health, January $20^{\text {th }}$, a feature story on the health page

- My uncle violated me as a teen, I feel like committing suicide, March $8^{\text {th }}$, a letter on the "Relationships" page

- MTN foundation inaugurates centre at OOU to fight HIV/AIDS, June $25^{\text {th }}$, news story on a voluntary testing and counseling centre at the OlabisiOnabanjo University, Ago Iwoye, Ogun State

- 17 year old mother delivers premature baby at DELSUTH, August $11^{\text {th }}$ news story

- Is it wrong to be deflowered at 19? Page 15, August $25^{\text {th }}$, a letter on the relationships page

- 3 sisters in court for raping 22-year old man, November $3^{\text {rd }}$, news story on rape

- Another rapes 17-year old, feigns sickness December $2^{\text {nd }}$ news story on rape, "another" indicates there was another story on rape but which is outside the scope of the study

- Virginity test: Ogun govt suspends principal, December $20^{\text {th }}$ news story on a secondary school principal that authorized virginity test on her students without the parents' consent

- Virginity test on secondary school students, December $28^{\text {th }}$ editorial comment on virginity test in an Ogun State secondary school.

\section{Daily Sun}

A total of eleven (11) stories were identified on sexual reproductive health/rights and HIV/AIDS issues affecting young people aged 15-24 years in Daily Sun from January to December 2012, which was $10.89 \%$ of the 101 total stories on SRH and HIV/AIDS in the newspaper for the period under review.

The stories were the following:

- My father's friend denied me job because I refused to sleep with Him, January 14th, 
relationship column

- 17 teenagers gang rape 35-year old woman, February 10th, news

- Robbers hijack luxury bus, rape students, April 2nd, news

- Our ordeal by school girls raped by robbers, April 3rd, news

- Rape of school girls Police arrest driver, 4 suspects, April 4th, news

- Rape of school girls, April 11th, feature

- 7 boys gang rape girl, 15, in Rivers, April 12th, news

- My sister's death made me a reproductive health activist, May 18th interview

- How girl, 23, was killed for resisting rape, August 27th, news

- Undergraduate launches book on marriage, HIV/AIDS, September 1st, news

- $\quad$ Raped and abused 16-year old girl cries for help, September 15th, news

\section{The Punch}

There were a total of four (4) stories on SRH, sexual rights, and HIV/AIDS for youth aged 15-24 years. These stories represent $4.04 \%$ of the 99 total stories on SRH and HIV/AIDS published in the newspaper for 2012. They were:

- Robbers attack luxury bus, rape school girls, April 2nd, news

- Educating the adolescent girl on sexuality, August 12th, features

- Teenagers and morning after pill, December 9th, foreign feature from The New York Times syndicate

- Virginity test: Parents accuse principal of hidden agenda, December 25th, news story on a secondary school principal who arranged virginity tests for girls in her school.

\section{The Guardian}

The newspaper had six (6) articles related to youth aged $15-24$ years representing $\mathbf{2 . 4 3} \%$ of the total 247 articles on SRH and HIV/AIDS.

The stories were:

- How we were robbed, raped, April 3rd, news of some secondary school students that were allegedly raped after robbers attacked their bus

- $\quad$ Police arrest suspect in gang rape, April 4th, news

- Raped, robbed and traumatized forever, April 6th, Opinion

- How long should a woman remain a virgin, May 26th, Column

- Young people bear highest burden of HIV/AIDS, Jun 29th

- Group warns Parents, Girls Against Abortion, Jul 21st 


\section{Aminiya}

Aminiya had only one story on SRH and HIV/AIDS related to AYP aged 15-24 years in 2012 out of the 28 stories on SRH and HIV/AIDS published.

\section{IDEOLOGICAL ORIENTATION OF MEDIA TREATMENT OF AYP-RELATED HIV AND SRH ISSUES}

From the analysis, the Nigerian media is still hesitant and conservative in its treatment of AYPrelated HIV and SRH issues. There are no regular pages or columns devoted specifically to treating these issues - this was confirmed by the editors interviewed for this study (see next chapter).

Daily Trust was a bit more liberal by writing on issues like child marriage, a significant issue in the northern part of Nigeria, and child sexual abuse but the paper remained conservative in not advocating or supporting contraceptive usage for youth in the 19 stories published on youthrelated SRH and HIV issues. There was a story advocating that girls should be at least 18 years old before getting married and another on girl child education and early marriage. It further informed its readers on how to prepare for a girl's first menstruation in a story directed at the parents and not the girls themselves. Another story was on how to prevent children from sexual abuse, again targeted at parents.

Tribune published a story on its relationships page presumably written by a teenager asking "Is it wrong to be deflowered at 19?" with the person responding, a journalist with the newspaper, answering that it is wrong and recommending abstinence. There was no other reference to youth sexual activity or acknowledgement of other sexual orientations apart from heterosexual in all the stories analyzed. There was, however, a piece on how teenagers can stay healthy when pregnant.

Sun did not go beyond its news items, overwhelmingly focused on reports of sexual violence, and the report on a book written by an undergraduate on marriage and HIV/AIDS. Punch had a story on teenagers and the morning after pill which was sourced from a foreign publication while its piece on educating the adolescent girl on sexuality, a feature piece appeared more liberal but did not spell out the details of what access to a "full range of SRH services" means.

The Guardian's sole story on virginity and youth advocated that a woman should remain a virgin till she marries; it did not discuss abstinence for men. As previously mentioned, Aminiya had only one story that was youth-related on SRH and HIV/AIDS. The story was an editorial that raised an alarm on the high rate of promiscuity, rape, and prostitution among young girls which encouraged curbing "indecency" as a solution but never mentioned sexuality education or any other form of intervention for the young girls apart from religious and moral persuasion.

\section{LINKAGE OF YOUTH-RELATED SRH AND HIV/AIDS ISSUES TO BROADER HEALTH AND DEVELOPMENT ISSUES}

There were no attempts at linking many of the stories published by the newspapers on AYPrelated SRH and HIV/AIDS to broader development issues like the Millennium Development Goals, increased productivity arising from a healthy population of AYP and longer retention of the girl child in school. Only one story, the girl child, education and early marriage in Daily Trust touched on some of these issues.

\section{ANALYSIS OF NAIRALAND FORUM}

Nairaland Forum was started in 2005 by Oluwaseun Osewa according to information sourced from the website. Osewa is a computer programmer and the site is principally a discussion forum 
where members must be registered with a verifiable email address before they are allowed to post on the site.

All members have a Nairaland profile or name with which they post and many do not post using their true names. Posts range from issues on science and technology, programming, web masters, computers, phones, art, graphics and video, entertainment, market, car track, music/radio, romance, sports and others. At the time of writing this report, there were 1,167,452 members posting on 1,468,570 topics.

A total of 302 web pages were examined for postings on health with 293 postings on SRH and HIV/AIDS. Forum members do not post their ages so it is at times difficult to ascertain if some posts are youth-related. The SRH related posts range from those seeking SRH related information like where to terminate pregnancy to reporting of information sourced from newspapers, news web sites, and news agencies locally and abroad. Some attempted to use the site as a sort of "consulting room" for their medical issues tagging their posts with phrases such as "doctors in the house, please help."

\section{Content of SRH Posts}

Topics addressed in the posts include circumcision, infertility, abortion, impotency, sexually transmitted diseases, breast feeding, breast cancer, and menstruation. On HIV/AIDS, the posts were on where can one be tested, whether one knows his or her status or not, ways of infection, treatment, and cure. There was only one post on homosexuality, titled Homosexuality and HIV/AIDS In Nigeria, where the forum member condemned homosexuals and concluded that

\footnotetext{
"While we must maintain zero tolerance to homosexuality in all its faces let us know that only a power beyond them can break them lose from this destructive habit. Are you there and you're a homosexual? Is it possible that you've bought the most common but very false excuse that goes, " God made me this way. I didn't choose to be like this" ...? Well I must tell you, that's a lie and you know it."
}

There was no response to the post apart from another person wanting to find out information on when to be tested after having sex with an HIV positive person.

There were also posts on a supposed cure for HIV/AIDS ranging from coconut oil to "revelations" from heaven or God, and adverts on where to go for different kind of health ailments. The posts do not appear to be regulated or to have any means of fact checking.

Examples of posts on the site include: What Drug Can A Pregnant Woman Felling Malaria Take?; Menstrual Cycle....U Must Read Even If You Do Not Use It; Available: This Works Well For HIV Patients; Engineered Stem Cell Kill HIV Infected Cells In A Living Organism; For Free Ivf Consultation Call 08038183212; My Fiancee Told Me To Go On Family Planning. Is He Right?;Virgin Coconut Oil Kills Hiv Viruses and Viruses That Have Lipid (fatty); My Girl Is Scared Of Going Through A D\&c Operation; Need Pregnancy Within 2 Months Without Drug Or Surgery Even at 59? Relax; I Want To Abort Please Help; Odumegwu Herbal Tea For HIV Cure; The Role of Moringa Leaf Powder In Treating HIV And AIDS. Some posts were stigmatizing like one titled Fear Of HIV Scourge Seizes Kano As 44 'prostitutes' Test Positive.

\section{Youth-Related posts on SRH and HIV/AIDS}

Only three posts contain ages within the study group and these are: Omg A Virgin With Hiv Aids (early 20s), Imagine, Still A Virgin Boy At 22 yrs and Heavy Bleeding After Aborting Pregnancy With Cytotec (23 years), Early Marriage And The " $v$ " Word. There was one other posting - January 17, 
My Girl is scared of going through a $D \&$ C operation, which was centred on young people but without specific reference to the age group of interest. Additionally, there were two posts that focused on adolescents but those younger than age 15 - January 18, Female circumcision Edirin's story and February 9, Girls, 13 contraceptive implants a school (re-posted from a British newspaper).

The first youth-related post was made on June 3, 2012 and was titled Omg A Virgin With HivAidz. Imagine and read:

There is dis young nigeria girl in her early 20 s she just finished her service and she is preparing to settle down, but she is infected with the deadly uncurable deseases called HIV AIDS, the question is can she get a husband, can she ave a solutn to ha problem, ishiv aid truely incurable.

There were 26 responses to the posting with most respondents concentrating on insulting the person who drafted the post for his or her ignorance.

The second posting was made on June 16:

Gud day 2 you all... Am a 22yrs old male, a Graduate of Marketing. About to go 4 NYSC Batch B nxt month. I am still a VIRGIN. Sometimes i feel pains in lower abdomen and testicles. Hope it isn't a sickness and does being a virgin at dis age have a negative effect? Pls, the Doctors in the house should advise me... At moderator, pls help make sure dis gets 2 the front page.

Three people responded to the posting and all encouraged the young man to maintain his virginity with one stating "abstinence until marriage is the way to go." One person recommended physical exercises for him to reduce the abdominal pain.

The third was posted on February 26 and was titled To any doctor based in Lagos. It read as follows:

"First, I am so sorry for intruding into this forum but i believe this is the only place where help come.

I believe we all make mistakes and sometimes we take decision that are ought not to have been taking, Here is my story: My name is Nicholas, I have a lady aged 23yrs that i loved so much and we've been dating right from university years. To go straight to the point, we had unprotected sex that leads to pregnancy which had reached 4weeks of its gestation age before we noticed, we make a drastic decision of aborting the pregnancy because we are not ready for it. And the matter became worse when all the hospitals we visited refused to do the abortion for us.

We were in confused state as we do not know the next thing to do. I personally resolved in searching for the drug that can abort pregnancy online which I later find (mifepristone and cytotec), we were unable to find mifepristone in pharmacy shop but we do find cytotec. She took cytotec alone $(800 \mathrm{mcg}) 200 \mathrm{mcg}$ each. She started bleeding 30 minutes later and continues like that till the following day with so much pain. She took another $800 \mathrm{mcg} 2$ days after as the instruction indicated and the bleeding stopped the following week. She went for scan 2 weeks later 
and no traces of pregnancy was find. We thought that was all but she developed fever and was admitted to hospital and discharged 2days later after treatment.

Ever since the abortion, she bleeds everyday continuously or the bleeding stops today and starts again the following day. She puts on pad everyday, (today 25-02-12 will make it 39th day that she's been bleeding non-stop). The bleeding sometimes will be light that she can use one pad for 2 days and sometimes, 2 or 3pads in day.

I went back online and read about the aftermath of the drug and checked discussion forum, some complains of bleeding for 3months even after they have consulted doctor and some even more.

Please, we know we have made mistakes but we need help. She cries everyday and i do feel her pain, what can we do to solve this problem?

Thanks to you all!

I can be contacted on.

This attracted 86 responses which could be categorized as follows: 54 people recommended taking the young woman in question to a hospital immediately; 20 hurled insults at the young man and some of the responders; seven people offered prayers for him and the society; four were indifferent preferring instead to exclaim or ponder and one person advocated for condom usage next time. Some of those who asked the young man to seek care in a hospital would like abortion to be legalized in Nigeria as gleaned from their comments.

The final youth-related post titled Early Marriage And The " $v$ " Word, focused on the reproductive health (mostly vesicovaginal fistula) and socioeconomic implications of early marriage of adolescent girls. The article was reposted from http://deltawomen.blogspot.com. It only received one response which simply stated "anyone from age 18 is an adult and can be legally married." 


\title{
Key Informant Interviews
}

\section{INTRODUCTION}

A total of nine (9) people were interviewed for the key informant interviews (see Appendix for the interview questions). These were the editors and the health correspondents of the newspapers used for this study: Daily Sun, Nigerian Tribune, The Guardian and The Punch. Five health correspondents and four editors were interviewed.

\section{RESPONDENTS' BACKGROUND}

All but one newspaper editor had a second degree. The only editor who did not have a second degree had a postgraduate diploma in Journalism. All the health editors/correspondents studied one of the biological sciences with courses of study including Biochemistry, Zoology, Botany and Microbiology. None of the editors has a background in the sciences, either physical or biological. Two of the correspondents were female while none of the editors was female. The least experienced respondent had four years of journalism practice while the most experienced had been a journalist for 25 years.

\section{KNOWLEDGE OF HIV/AIDS EPIDEMIC IN NIGERIA}

All of the respondents displayed a good grasp of the HIV/AIDS epidemic in Nigeria clearly enunciating the modes of transmission, the level of disease burden, its impact on our socioeconomic life and how it affects adolescents and young people. However, one, a newspaper editor, said he does not believe it is an epidemic.

"I don't believe that at all, I suspect these NGO people are just saying that because of donor funds."

Some of the other responses include:

\begin{abstract}
"It is on the increase and people are not particularly careful. The epidemic is one of the most unfortunate things we have in Nigeria and it has been a burden not just to the health care system but to Nigeria." (Health Correspondent).
\end{abstract}

\begin{abstract}
"I know quite a lot. I know about the means of transmission and the new treatment guidelines released by the Federal Ministry of Health."(Health Correspondent) "I know that about 3-4\% of Nigerians are HIV positive and some have died of AIDS-related complications with some dying without others knowing. I know that going by figures from government, the rate of infection is declining because at some point the awareness was very high." (Editor)
\end{abstract}

\section{Knowledge of the HIV/AIDS epidemic and how it affects youth aged 15-24 in Nigeria}

Eight respondents agreed that this age group is the most vulnerable because they are very active and want to experiment with a lot of things while the ninth respondent said he did not know.

\section{EXPLICIT POLICY OR SPECIAL INTEREST IN COVERING SRH AND HIV/AIDS ISSUES}

None of the organizations that the respondents worked for has an explicit policy on covering 
SRH and HIV/AIDS issues. One, an editor, said his organization has a policy but when asked of the contents of the policy, he said, "Actually it is not written down in such sense but I just know we focus on that group in our newspaper coverage."

All respondents similarly claimed to have a special interest in covering issues related to $\mathrm{SRH}$ and HIV/AIDS issues affecting youth.

\section{REGULAR SOURCES OF HIV/AIDS AND SRH-RELATED STORIES}

They all cited development agencies as their regular sources of HIV/AIDS and SRH related stories with UNICEF, WHO, UNAIDS, and UNFPA consistently mentioned. Two respondents named the National Institute of Medical Research (NIMR) in Yaba, Lagos State as a source with one adding that because of the HIV clinic that the institute runs; "it is always a nice place to go for stories as I can also meet those living with HIV there anytime I go." They all expressed distrust for any government agency in Nigeria as a source of data for their stories. Only one mentioned USAID as a source of stories.

\section{PUBLISHING STORIES ON HIV/AIDS AND SRH ISSUES AFFECTING YOUTH}

All respondents mentioned that they publish SRH and HIV/AIDS stories as the need arises and not on specific days and would treat such stories like any other story without any special action but only on journalistic terms like timeliness, newsworthiness, topicality, balance, fairness, and reflecting all sides. Only three respondents admitted that they have covered an "HIV/AIDS and SRH related controversy" claiming that they treated those stories like any other story but the reactions that trailed them made such stories controversial. Examples cited include stories about a baby that was given infected blood, a person living with HIV (PLWH) that was sacked because of her status but who was later reinstated on the orders of a court, and the "zip -up" campaign because of the controversies surrounding condom usage.

\section{"An example is any story on teenage abortion and adolescent and young people access to contraceptives" (Health Correspondent)}

\section{"Zip-up campaign was not an easy message but with the help of the Federal Ministry of Information we played it up very well. I think it is still not popular advocating for condoms usage among adolescents and young people." (Health Correspondent)}

A health correspondent, however, said "As much as possible I don't dabble too much into controversial issues because these are days that if you mistakenly do a story and it becomes libelous, the company will hold you responsible. So I run away from it. I don't want trouble."

All the health correspondents said they have been approached by a public health-related professional or institution to cover or report on HIV/AIDS and/or SRH-related issues and that they were satisfied with the outcome as it particularly helped them to network and make contacts that are useful for the future. The editors said they have never been approached, as they were not covering such issues before they became editors but their staff have been invited and they honoured such invitations.

They were in agreement that a lot needed to be done to improve the coverage of HIV/AIDS and SRH issues among youth aged 15-24. Some of their suggestions included building the capacity of reporters to cover stories appropriately and more active awareness creation and public discussion by key agencies. 
"They must first of all build capacity. One thing is to have the story; another thing is to recognize it. Sometimes when we talk about controversial issues, if your capacity is high and you report them appropriately, nobody will be offended at the end of the day. As they build capacity of researchers, they must also build the capacity of reporters to be able to understand issues as they are and run along with it." (Health Correspondent)

Another health correspondent said, "There should be more awareness, agencies should do more and invite the press to disseminate information to the media and subsequently the general public."

\begin{abstract}
"The NGOs and agencies must keep their issues on the front burner. Events and issues surrounding them must be generated so that we can take their issues more seriously. It is just an addendum presently now but they ought to be taken seriously so that we can break the secrecy surrounding young people and adolescents living with HIV/AIDS. It is easier to see a married woman with her children going for treatment than an adolescent because of stigma and that is why we need to keep talking about them." (Health Editor)
\end{abstract}

All respondents expressed willingness to do more in improving coverage.

\title{
IDEAL SRH AND HIV/AIDS STORY AMONG YOUTH
}

No respondent clearly stated what would make an ideal story or article in the media on HIV/AIDS and SRH issues among adolescents and young people aged 15-24 but majority expressed a preference for data on number of infected people, information on cures for HIV, data on donor funds, and stories about holding the government more accountable on its mandate to control the spread of HIV.

\section{CAPACITY BUILDING ON COVERING HIV/AIDS AND SRH RELATED ISSUES}

All respondents claimed that their organizations have trained them but none was able to cite any training session organized specifically on covering HIV/AIDS and SRH related issues. Answers included:

\footnotetext{
"We train generally to ensure that our reporters are effective in any beat they find themselves.” (Editor)

"We have sent our anchorman on a number of courses to build capacity to be able to explain and interpret data." (Editor)
}

"Yes, indirectly," was the response of a health correspondent.

"That I will not answer. It is a policy issue," said another correspondent.

A correspondent, however, cited the fact that some media houses re-assign reporters to different beats as a reason for her organization not providing training for its staff on reproductive health reporting. "They train generally and not for specific beat reporting. They cannot say they will train only on reproductive health issues. It is too narrow. They have to train everybody, give them the basic skills for their job. These are days that people change 
beats. They cannot afford to train you for health alone. What if they need people for political reporting?" she asked.

Another correspondent said, "No, not specifically on HIV/AIDS."

However, two respondents endorsed having attended trainings organized by international agencies on covering HIV/AIDS and SRH related issues. 


\section{Summary, Conclusion, and Recommendations}

\section{SUMMARY}

The content analysis of SRH and HIV/AIDS issues among AYP as reported in some Nigerian newspapers has revealed a huge gap in the coverage of such issues in Nigeria print media. While Nigerian newspapers are reporting more on these issues, they are not focusing on how these issues concern AYP. The newspapers had a total of 746 stories on HIV/AIDS, sexuality, sexual health and sexual rights published in 2012. Aminiya, a Hausa language newspaper, published 28 in its 52 editions during the same period. For the six newspapers, however, only 50 of those stories focused on AYP aged 15 - 24 years, which represent $6.7 \%$ of the total articles published that related to HIV/AIDS and SRH. Aminiya had only one piece focused on AYP aged $15-24$ years.

Only Aminiya, Daily Trust and Nigerian Tribune published editorials on HIV/AIDS, sexuality, sexual health and sexual rights during the period. Only these three papers considered the issue strong or worthy enough to comment on as editorials but only one of the editorials was on AYP, a recognized vulnerable group.

In terms of percentages, Daily Trust is the newspaper with the most coverage of AYP related SRH and HIV/AIDS issues with nineteen (19) related stories in the period under study. Although, The Guardian had the highest number of stories on the issues - 248 - it had only six (6) focusing on AYP aged 15 - 24 years, at 2.43\%. Daily Sun ranks second with a total of 101 stories but 11 published $-10.89 \%$ with a focus on the age group. The Punch published 99 stories but had a total of four stories on AYP aged 15 - 24 years, which is $4.04 \%$.

Another concern is that only the Daily Trust published an investigative story in the period under review, a story on VVF titled Not just in the north, VVF also occurs in south. Most of the stories were reports of activities or events, which generated more sound bites for journalists than serious in-depth research that articulated issues or a cause. There was no story among the 746 analyzed that focused on sources of finance for SRH and HIV programs and government financial accountability in terms of SRH and HIV/AIDS programming.

The ideological persuasion of the 50 stories was conservative as only one of them was bold enough to advocate for AYP taking charge of their sexuality, a piece on adolescent girls and sexuality which discussed the negative effects of early births on adolescent girls and advocated for "broad and continuous sexuality education" and "access to full range of SRH services." It is also noteworthy that two health correspondents interviewed for this analysis said that stories about condom usage and the "zip-up" campaign (mass media campaign that promoted sexual abstinence for AYP) are controversial stories.

A significant amount (48\%) of the AYP-related HIV/SRH coverage was dedicated to sensational coverage of sexual violence (mostly rape) inflicted on or perpetrated by AYP. The existence of diversity in sexual orientation was admitted in the stories on homosexuals but apart from the news report on a lawyer challenging the bill prohibiting same-sex marriage in court, the other stories on homosexuality were negative. Additionally, there was a preponderance of stories on events and statistics without deliving into them further or situating them in their context

It was challenging analyzing the youth focused nature of posts on Nairaland forum as only four $\mathrm{HIV} / \mathrm{SRH}$ related postings on the website contained ages which fell in the AYP category focused on for this study. The responses to the postings show that abortion is still viewed as a "devilish act" by "ungodly people" who deserve the strictest punishment. Many postings on the website though not directly focused on AYP revealed that some Nigerians still have limited access to confidential, 
accurate and comprehensive information on sexual and reproductive health issues and utilize the forum to gain such information.

\section{CHALLENGES AND LESSONS LEARNT}

Some of the challenges and lessons learnt include:

- There were challenges accessing the newspaper copies as some of the media houses restrict access to their libraries.

- Newspaper archives need to be available in easily accessible formats for research purposes.

- Need for proper newsprint archiving and documentation systems in local, state and national libraries.

- There is need for a better record-keeping culture in the print media as evidenced by the fact that some of the newspapers did not have their own newspaper copies published in 2012. Of note the Guardian newspaper commenced a digitization process of its library while this study was being conducted. This should aid in improving accessibility of back issues of its publications.

- Speaking to key personnel of the media houses provided more insight into the context behind the printed words.

\section{CONCLUSION}

The level and quality of reportage of SRH and HIV/AIDS in relation to adolescents and young people aged 15 - 24 years is very low, in fact virtually nonexistent as this content analysis shows. There is, therefore, an urgent need to remedy this gap as the media still have a great role to play in educating, informing, and advocating for change in peoples' attitude and understanding of sexuality in Nigeria.

There is also a heavy concentration of reporting on rape, especially as it affects minors in the country but it is difficult to say whether there is an upsurge in rape or merely an upsurge in reportage of such incidents. Further research is needed in this area to draw a verifiable conclusion especially as such stories emanated from police incident reports and not necessarily from a SRH or gender based violence perspective.

While none of the five newspapers has a deliberate policy of targeting adolescents aged $15-24$ years in their reportage, their editors and science/health correspondents expressed that this group is one they focus on but apparently not in the area of their sexual and reproductive health and rights. There is, however, an acknowledgment that this should change and also a willingness to collaborate with individuals and organizations that are ready to work with journalists in improving coverage. And while coverage can be improved, these journalists know where they need to turn to for information even though they lack confidence in government agencies and organs for statistics on SRH and HIV/AIDS issues.

Similarly, while some of these newspapers regularly train their staff on reporting, none of the journalists interviewed said they have attended training solely on $\mathrm{SRH}$. There is still a fixation on statistics as they relate to number of patients, budgetary figures, and mortality figures without a focus on in-depth background reporting or situating these figures in their proper context. 


\section{RECOMMENDATIONS}

The media needs support in filling the gaps identified above and there is a need for editors and other newspaper content shapers to recognize this reality. The following are some suggestions that can help remedy this situation:

- Training of media professionals in HIV and SRH: The media (e.g., reporters, line editors, title editors, and publishers) need to be approached as allies in educating and reducing the burden of HIV/AIDS and other myths surrounding sexual and reproductive health. Trainings, especially on sexuality and reproductive health and HIV/AIDS reporting should be organized regularly for these four categories of people. Pertinent governmental and non-governmental stakeholders can sensitize the Nigeria Guild of Editors (NGE) in their annual sessions or on a zonal basis on the need for a purposeful and focused reporting of these issues as they affect AYP aged $15-24$ years.

- Invite journalists and other media gatekeepers to events and program activities: Development organizations, governmental bodies, and researchers should invite members of the media to events and program activities. Courtesy calls should also be encouraged so that a long lasting mutually beneficial relationship can be developed. Many research projects are being implemented without the public knowledge and results should be presented in a format that the public can digest. Press packs or briefing packs should be developed by a communication specialist in conjunction with researchers on key points of research findings. These packs along with contact information for experts/individuals that can readily be interviewed should be distributed to journalists.

- Make readily available contact information of in-house subject experts: Organizations can display on their websites a contact list of experts available inhouse that can discuss specific issues as the need arises since story development times in journalism can be quite short. When engaging with the media, the experts must insist on written questions and the thrust of the particular story so that comments, views or facts are not taken out of context. The latter occurrence is the reason in-house communication specialists are needed to provide guidance to area experts/researchers. These communication specialists can also serve the purpose of "selling" specific stories to journalists who may otherwise not think of a particular issue as news worthy. They will ferret out interesting angles, story pegs or hooks with which journalists are sent information or called or visited to consider reporting such stories.

- Sponsoring journalists to attend conferences and meetings: Sponsorships of journalists to attend conferences and meetings both locally and internationally is also a way of rewarding and motivating journalists who have distinguished themselves in covering a particular issue well.

- $\quad$ Engaging the News Agency of Nigeria (NAN): Any engagement with journalists must consider engaging with the News Agency of Nigeria (NAN), a wire service owned by the federal government, as it appears to be the source of many stories on HIV/SRH that Nigerian newspapers publish.

- Funding a short-term fellowship (1-2 weeks) and/or a competition for journalists: Organizations should consider funding a fellowship that would enable journalists to spend time out of newsrooms reporting on specific issues. There can also be competitions designed solely for journalists on sexual and reproductive health 
issues with a panel of judges comprising senior journalists and development practitioners. Prizes can thereafter be awarded to winners. This would engender competition among journalists covering the health beat.

- Engaging with schools of journalism: There should be engagement with journalism teachers particularly in teaching health reporting in the journalism schools so as to improve coverage of sexuality and reproductive health and HIV/AIDS-related issues.

- Utilize online platforms for provision of comprehensive sexuality education: Online forums, like Nairaland, are an untapped platform to provide Nigerians with accurate and comprehensive sexuality education. Governmental and non-governmental organizations should explore ways to utilize these forums for information dissemination especially for adolescents and young people. 


\section{References}

1. Federal Ministry of Health [Nigeria] (2013) National HIV/AIDS and Reproductive Health Survey, 2012 (NARHS Plus II 2012). Federal Ministry of Health Abuja, Nigeria.

2. National Population Commission Abuja: 2006 Population and Housing Census of the Federal Republic of Nigeria Priority Tables (Volume 1) 2009.

3. National Agency for the Control of AIDS (2013) President's comprehensive response plan for HIV/AIDS in Nigeria. (Abuja: The Presidency).

4. UNAIDS, Global Report Annexes 2012

5. National Agency for the Control of AIDS (2010). National HIV/AIDS Strategic Plan 20102015. (Abuja: The Presidency).

6. UNDP Human Development Report 2013

7. Federal Republic of Nigeria (2012). Global AIDS Response Country Progress Report: Nigeria GARPR 2012. (Abuja)

8. Nasidi A, Harry TO (2006) The epidemiology of HIV/AIDS in Nigeria. In: Adeyi O, Kanki PJ, Odutolu O, Idoko JA, editors. AIDS in Nigeria: a nation on the threshold. Cambridge (Massachusetts): Harvard Center for Population and Development Studies.

9. Odutolu O, Ahonsi BA, Gboun M, Jolayemi OM (2006). The national response to HIV/AIDS. In: Adeyi O, Kanki PJ, Odutolu O, Idoko JA, editors. AIDS in Nigeria: a nation on the threshold. Cambridge (Massachusetts): Harvard Center for Population and Development Studies.

10. National Population Commission (NPC) [Nigeria] and ICF International (2013) Nigeria Demographic and Health Survey 2013- Preliminary Report (Abuja: National Population Commission and ICF International).

11. Nwaorgu OC, Onyeneho NG, Okolo M, Obadike E, Enibe G (2008). Reproductive health knowledge and practices among junior secondary school grade one students in Enugu State: threat to achieving millennium development goals in Nigeria. East African journal of public health. 5(2):126-32. Epub 2008/11/26.

12. Adedimeji AA, Omololu FO, Odutolu O (2007). HIV risk perception and constraints to protective behaviour among young slum dwellers in Ibadan, Nigeria. Journal of health, population, and nutrition. 25(2):146-57. Epub 2007/11/08.

13. Olugbenga-Bello Al, Adekanle DA, Ojofeitimi EO, Adeomi AA (2010). Barrier contraception among adolescents and young adults in a tertiary institution in Southwestern Nigeria: a cross-sectional descriptive study. International journal of adolescent medicine and health. 22(2):321-9. Epub 2010/11/11.

14. Owolabi AT, Onayade AA, Ogunlola IO, Ogunniyi SO, Kuti O (2005). Sexual behaviour of secondary school adolescents in Ilesa, Nigeria: implications for the spread of STIs including HIV/AIDS. Journal of obstetrics and gynaecology. 25(2):174-8. Epub 2005/04/09.

15. Amoran OE, Fawole O (2008). Parental influence on reproductive health behaviour of youths in Ibadan, Nigeria. African journal of medicine and medical sciences. 37(1):21-7. Epub 2008/09/02.

16. Odu OO, Asekun-Olarinmoye EO, Bamidele JO, Egbewale BE, Amusan OA, Olowu AO (2008). 
Knowledge, attitudes to HIV/AIDS and sexual behaviour of students in a tertiary institution in south-western Nigeria. The European journal of contraception \& reproductive health care. 13(1):90-6. Epub 2007/09/22.

17. Ijadunola KT, Abiona TC, Odu 00, ljadunola MY (2007). College students in Nigeria underestimate their risk of contracting HIV/AIDS infection. The European journal of contraception \& reproductive health care. 12(2):131-7. Epub 2007/06/15.

18. Bamidele JO, Abodunrin OL, Adebimpe WO (2009). Sexual behavior and risk of HIV/AIDS among adolescents in public secondary schools in Osogbo, Osun State, Nigeria. International journal of adolescent medicine and health. 21(3):387-94. Epub 2009/12/18.

19. Adeyinka DA, Oladimeji O, Adeyinka EF, Adekanbi IT, Falope Y, Aimakhu C (2009). Contraceptive knowledge and practice: a survey of under graduates in Ibadan, Nigeria. International journal of adolescent medicine and health. 21(3):405-11. Epub 2009/12/18.

20. Morhason-Bello IO, Oladokun A, Enakpene CA, Fabamwo AO, Obisesan KA, Ojengbede OA (2008). Sexual behaviour of in-school adolescents in Ibadan, South-West Nigeria. African journal of reproductive health. 12(2):89-97. Epub 2008/08/01.

21. National Population Commission (NPC) [Nigeria] and ICF Macro. 2009. Nigeria Demographic and Health Survey 2008. Abuja, Nigeria; National Population Commission and ICF Macro.

22. Population Council. Child Marriage Briefing: Nigeria. 2005. New York: Population Council.

23. Erulkar AS, Bello M (2007). The experience of married adolescent girls in Northern Nigeria. Population Council, Abuja, Nigeria.

24. Oshi DC, Nakalema S (2005). The role of teachers in sex education and the prevention and control of HIV/AIDS in Nigeria. Sex Education, 5(1), 93-104.

25. Operario DE (2005). 'Commentary: Mass media interventions for promoting HIV testing' International Journal of Epidemiology. 35: 233 - 236.

26. Utulu, AU (2011). The Effects of Advertisement Messages: The Case of HIV and AIDS Awareness Campaign in Nigeria. Journal of Biology, Agriculture and Healthcare, 1(1), 1326.

27. McCombs ME. \& Shaw DL (1993). The evolution of agenda setting research: twenty five years in the marketplace of ideas. Journal of communication, 43(2), 58-67.

28. University of Twente. Framing. Accessed at http://www.utwente.nl/cw/theorieenoverzicht/Theory\%20clusters/Communication\%20Pr ocesses/Framing/.

29. Fatusi AO and Jimoh A (2006). The roles of behavior change communication and mass media 'AIDS in Nigeria: A nation on the threshold.' Harvard Center for Population and Development Studies. 
30. Leo R (2012, September 4). Stigmatisation, discrimination almost ruined my life. The Daily Trust. Retrieved from http://www.dailytrust.com.ng

31. Akpabio E. (2005) cited in Utulu, AU (2011). The Effects of Advertisement Messages: The Case of HIV and AIDS Awareness Campaign in Nigeria. Journal of Biology, Agriculture and Healthcare, 1(1), 13-26.

32.UNFPA. UNFPA in Nigeria. Accessed at http://www.unfpa.org/hiv/gyp/profiles/Nigeria.htm

33. BBC World Service Trust. A decade of transforming lives through media: ten stories of change. pg 9. Accessed at http://r4d.dfid.gov.uk/PDF/Outputs/MediaBroad/trust at_10_web.pdf

34. BBC Media Action.Touching lives, tackling stigma and delivering long-term change. Accessed at http://www.bbc.co.uk/mediaaction/where_we_work/africa/nigeria/flava.html

35. Abdulraheem M, Adisa RM, La'aro AO (2012). Information technology revolution and the future of print media in Nigeria: usage across age groups. Advances in management. 10(1):29-40. 


\section{Appendix : Key Informant Interview Guide}

Towards More Informed Responses to the HIV/AIDS Vulnerabilities of Nigeria's Youth

Media Content Analysis Key Informant Interview Guide

Key Informant (KI) Roster for Interviews

Location of Interview:

Interviewer Name:

Date $(\mathrm{dd} / \mathrm{mm} / \mathrm{yy})$ :

\begin{tabular}{|c|c|c|c|c|c|}
\hline Name & Position/Title & Gender & $\begin{array}{l}\text { Field of } \\
\text { Specialization }\end{array}$ & $\begin{array}{l}\text { Highest } \\
\text { Academic } \\
\text { Qualificati } \\
\text { on }\end{array}$ & $\begin{array}{l}\text { Years of Work } \\
\text { Experience in } \\
\text { Journalism (\#) }\end{array}$ \\
\hline & & & & & \\
\hline & & & & & \\
\hline & & & & & \\
\hline & & & & & \\
\hline & & & & & \\
\hline & & & & & \\
\hline & & & & & \\
\hline & & & & & \\
\hline
\end{tabular}

Key Informant Interview Guide on Print Media Coverage of HIV/AIDS and Sexual and

Reproductive Health (SRH) Issues among Adolescents and Young People aged 15-24 in Nigeria.

Informed consent

Hello, I am , working on behalf of the Population Council. You were identified for interview because as a key stakeholder within the print media in this country you will have deep understanding of the factors influencing newspaper publishing of HIV/AIDS and SRH related content especially as it relates to adolescents and young people aged $15-24$. Before you decide 
whether to grant me an interview, you need to understand why the interview is being held and what it would involve. Please take the time to read or listen as I read the following information. You may talk to others about the interview if you wish. Please ask me if there is anything that is not clear, or if you would like more information. When all of your questions have been answered and you feel that you understand why this interview is being conducted, you will be asked if you wish to continue with it, and if yes you and I will sign this Informed Consent form to indicate that you have agreed to be interviewed.

\section{Purpose of the Interview and Interview Requirements}

What is the interview about? The purpose of the interview is to find out about matters concerning how well media cover HIV/AIDS and sexual and reproductive health (SRH) issues among adolescents and young people aged 15-24 in Nigeria. We are interested in learning about factors that influence publishing articles on HIV/AIDS and SRH issues among adolescents and young people aged 15-24 years, sources of data used in some of the articles/stories, and what can be done to improve coverage of HIV/AIDS and SRH issues among adolescents and young people aged 15-24 years. We will make every effort to protect your privacy and confidentiality. There is no cost to you from participating in this study. Rather you may receive new insights on what other Nigerian media stakeholders are doing in terms of coverage of HIV/AIDS and SRH issues among adolescents and young people aged 15-24 in the course of the interview.

What will happen if I take part? If you agree to take part in the interview, we will ask you to sign this form. For purposes of accuracy of the information we will record the information using an audio tape which would be destroyed after the transcription of the recording for digital capture and analysis. In order to maintain anonymity your name will not be indicated in the notes from this interview or linked to the transcription of the interview. The purpose of this interview is to learn from your experience, views and perspectives and so there are no right or wrong answers. Please feel free to give your opinion in response to any of the questions and to refuse to answer any question that you may wish not to answer. If you have any questions or concerns about this study, you should contact XXXXXX (E-mail: xxxxxx@popcouncil.org and Tel: 000-000-000-0000).

How long will the interview last? This will take between one and half to two hours.

\section{Consent statement for signature}

I have read this entire consent form or that the interviewer has read it to me, and has answered any questions. I certify that I give my informed consent to take part in the inquiry.
Signature of the respondent
Date

Person who conducted Informed Consent discussion: I confirm that I have personally explained the nature and extent of the planned interview, procedures, and confidentiality of personal information.

\section{Name of person obtaining consent:}

Signature of person obtaining consent:

Date: 


\section{Interview questions}

1. What do you know about the HIV/AIDS epidemic in Nigeria?

2. What do you know about how the HIV/AIDS epidemic affects adolescents and young people aged 15-24 in Nigeria?

3. Does your newspaper have an explicit policy for or a special interest in covering HIV/AIDS and Sexual \& Reproductive Health (SRH) related issues?

a. If YES...What is the policy and what is the basis of that special interest?

4. Does your newspaper have an explicit policy for or a special interest in covering issues that interest or affect adolescents and young people aged 15-24?

a. If YES....What is the policy and what is the basis of that special interest?

5. What are your regular sources for HIV/AIDS and SRH related stories? Have you ever voluntarily approached a public health expert or institution to give information or views about HIV/AIDS and/or SRH related issues? Which sources for HIV/AIDS and SRH related stories do you value most and why?

6. How often do you publish stories on HIV/AIDS and SRH of adolescents and young people aged $15-24$ years in your newspaper? What are the sources for these stories?

7. How do you cover controversial HIV/AIDS and SRH related issues?

8. Give us one example of an HIV/AIDS and SRH related controversy that you reported or which your newspaper covered? How did you ensure that your reporting or coverage was fair, balanced, and informative?

9. How do you cover controversial issues that affect or interest adolescents and young people aged 15-24? 
10. Give us one example of a controversial adolescent and young people related issue that you reported or which your media organization covered? How did you ensure that your reporting or coverage was fair, balanced and informative?

11. What determines the stories that you publish? What are the sources of the data used in these stories?

12. Have you ever been voluntarily approached by a public health-related professional or institution to cover or report on HIV/AIDS and/or SRH related issues?

a. If YES...Did it relate to adolescents and young people aged 15-24?

b. Were you satisfied with the outcome, and why?

13. What can be done to improve coverage of HIV/AIDS and SRH issues among adolescents and young people aged 15- 24 years in your newspaper?

14. What, in your view, would make the ideal story or article in the media on HIV/AIDS and SRH issues among adolescents and young people aged 15-24?

15. Has your organization invested any resources in building the capacity of journalists to cover HIV/AIDS and SRH related issues?

a. If YES...Could you explain the nature of this investment?

16. Has your organization invested any resources in building the capacity of journalists to cover general youth and adolescent development issues?

a. If YES...Could you explain the nature of this investment? 
House 4, No. 16B P.O.W Mafemi Crescent Utako District, Abuja Nigeria

Ideas. Evidence. Impact.

popcouncil.org 